\title{
Studies on the Vibrio cholerae mucinase complex. II. Specific neuraminidase activity measured histochemically in a goblet cell assay
}

\author{
R. A. OLLAR and D. E. S. STEWART-TULL*
}

\section{Department of Microbiology Research Unit, Alexander Stone Building, Garscube Estate, Bearsden, Glasgow G61 10H}

\begin{abstract}
Summary. The activity of neuraminidase prepared from the mucinase complex of Vibrio cholerae was measured by a new, semi-quantitative goblet-cell assay. The counts of normal, alcianophilic, sialomucin-containing goblet cells (purple-stained) and neutral mucosubstance-containing goblet cells (magenta-stained) in serial sections of ileum were compared before and after neuraminidase treatment. The procedure provides a more natural assessment of the action of $V$. cholerae neuraminidase on the viscous intestinal mucus.
\end{abstract}

\section{Introduction}

Sialic acid moieties ( $\mathrm{N}$-acylated neuraminic acid) liberated by neuraminidase from glycoproteins (mucin) or mucopolysaccharides were detected by the colourimetric thiobarbituric acid assay of Warren (1959). This test assumed that all neuraminidases would have the same activity against one substrate, bovine submaxillary mucin. Developments of this assay have centred on the use of less viscous substrates, but these have fewer carbohydrate groups per molecule, as pointed out in a previous communication (Stewart-Tull et al., 1986). The more sensitive assays, such as those of Popenoe and Drew (1957), Hughes and Jeanloz (1964) or Fraser and Smith (1975), gave more accurate determination of neuraminidase activity of different micro-organisms. The substrate, $\mathrm{N}$-acetyl neuraminlactose (NAN-lactose) is sensitive although expensive (Cassidy et al., 1965). However, the National Institute for Allergy and Infectious Diseases (NIAID), Maryland have recommended the use of the artificial substrate 2-( $3^{\prime}$ methoxyphenol$\mathrm{N}$-acetyl $\alpha$ neuraminic acid) for the assay of Vibrio cholerae neuraminidase (see Palese et al., 1973). This assay measures the liberation of blue methoxyphenol from the substrate by neuraminidase isolated from a variety of viral, bacterial and mammalian sources.

Spicer and Warren (1960) used an alcian blue/ PAS staining procedure to designate neuraminidase activity as positive or negative; histochemically

Received 13 Dec. 1985; revised version accepted 10 Aug. 1986.

*Correspondence should be sent to Dr D. E. S. Stewart-Tull. there was a loss of alcianophilia in goblet cells. A similar effect was observed by Quintarelli et al. (1961) with bovine submaxillary mucin and rat sublingual gland mucin and by Wheeldon et al. (1976) with dog bronchus after treatment with influenza virus neuraminidase.

During studies of the mucinase complex of $V$. cholerae, the relation between the quantitative, invitro, colourimetric assays of neuraminidase activity and the histochemical reaction in tissue sections was examined. This paper describes a new gobletcell assay based on the numerical difference between the alcianophilic, normal goblet cells and magentastaining cells containing neutral mucosubstances that remain after treatment with neuraminidase.

\section{Materials and methods}

Vibrio cholerae NCTC 10732, the classical biovar, Inaba serovar, was obtained from the National Collection of Type Cultures, Colindale, London.

Production and purification of $V$. cholerae mucinase complex and estimation of neuraminidase activity. These procedures were described in detail by Stewart-Tull et al. (1986). The methanol precipitate of the crude culture filtrate of $V$. cholerae was purified by Sephadex G100 filtration. The fractions, eluted with $0.05 \mathrm{M}$ sodium acetate

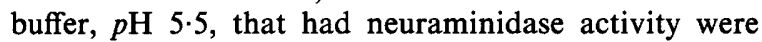
pooled and concentrated and this material is referred to as $\mathrm{G} 100 / \mathrm{N}$.

Cholera enterotoxin. Crude $V$. cholerae culture filtrate containing enterotoxin was kindly provided by the Research Resources Branch, NIAID, Bethesda, MD, USA.

Commercial neuraminidase preparations. Clostridium perfringens neuraminidase EC 3.2.1.18 was obtained from Sigma Chemical Co., Poole, Dorset; this has a potency 
of 680 international milli-units $(\operatorname{ImU}) / \mathrm{ml}$ and may contain aldolase and proteinase. An equivalent product from Worthington (Millipore UK Ltd, London) had a potency of $680 \mathrm{ImU} / \mathrm{ml}$ and contained $<0.1 \%$ proteolytic activity. $V$. cholerae neuraminidase preparations were obtained from (1) Koch-Light Laboratories, Suffolk (1 IU/ml; no detectable aldolase, phospholipase or proteinase) and (2) Calbiochem-Behring, Cambridge Bioscience, Cambridge $(1 \mathrm{IU} / \mathrm{ml}$; contains aldolase $<10 \mathrm{mU} / \mathrm{ml}$, phospholipase $<20 \mathrm{mU} / \mathrm{ml}$, and proteinases $<0.1 \mathrm{mU} / \mathrm{ml}$ ).

Histological procedures. The ileum was removed from a healthy guinea pig, rat or rabbit. Ileal segments were wrapped in aluminium foil and quickly frozen in liquid nitrogen. The frozen tissue segments were stored at $-170^{\circ} \mathrm{C}$, and subsequently removed from the foil and cut transversely into small lengths. Each segment was placed transversely in an aluminium foil boat $(2 \times 3 \mathrm{~cm})$ filled with Ames OCT freezing compound (Raymond Lamb Ltd, London). The foil boat was kept in an isopentane slurry, cooled with liquid nitrogen, until the tissue turned completely milky-white. The tissue block was removed and fixed to a cryostat chuck-face. Serial sections, $8 \mu \mathrm{m}$ thick, cut in a cryostat (SLEE Medical Ltd, London) at $-25^{\circ} \mathrm{C}$, were laid on glass microscope slides (precleaned with ethanol $90 \% \mathrm{v} / \mathrm{v}$ and coated with ovalbumin $0.1 \% \mathrm{w} / \mathrm{v}$ ) and placed at $4^{\circ} \mathrm{C}$ to thaw slowly.

Preservation of mucosubstances by paraformaldehyde vapour. The tissue fixation procedure was basically as described by Pearse and Tock (1965). A desiccator was completely dried in an $80^{\circ} \mathrm{C}$ oven; a crucible, containing paraformaldehyde powder (BDH) $5 \mathrm{~g}$, was placed inside the desiccator at room temperature. The lid was replaced and the vessel was heated at $80^{\circ} \mathrm{C}$. After $1 \mathrm{~h}$, the crucible was removed quickly and replaced with a tray of microscope slides holding sections of ileal tissue. The closed desiccator was kept at $60^{\circ} \mathrm{C}$ for $1 \mathrm{~h}$ and the slides were then removed for staining.

Alcian blue-periodic acid Schiff histochemical staining method $(A B / P A S)$. This was as described by Mowry and Winkler (1956). Sections were stained in alcian blue (Raymond Lamb, London; AB $10 \mathrm{~g}$ in $30 \mathrm{ml}$ of concentrated acetic acid made up to $100 \mathrm{ml}$ with distilled water) at $p \mathrm{H} 2.5$ for $30 \mathrm{~min}$. After washing in running water, the sections were treated with aqueous $\mathrm{HIO}_{4} 1 \% \mathrm{v} / \mathrm{v}$ for 10 min and washed again. The sections were counter-stained with Schiff's reagent [pararosaniline chloride (Kodak Ltd) $1 \% \mathrm{w} / \mathrm{v}$ decolourised with sulphur dioxide gas] for $10 \mathrm{~min}$, rinsed three times for $2 \mathrm{~min}$ in sodium metabisulphite $9.5 \% \mathrm{w} / \mathrm{v}$, rinsed in water, dehydrated, cleared and mounted in DPX.

\section{The effect of neuraminidase and other chemical treatments on goblet-cell histochemistry}

Two frozen paraformaldehyde-fixed transverse sections of rat ileum were treated for $14 \mathrm{~h}$ at $37^{\circ} \mathrm{C}$ in a moistened chamber with $0.2 \mathrm{ml}$ of one of the following: (i) distilled water; (ii) $0.05 \mathrm{M}$ sodium acetate $(\mathrm{NaAc})$ buffer, $p \mathrm{H} 5.0$ or 5.5; (iii) C. perfringens neuraminidase (Worthington); (iv) C. perfringens neuraminidase
(Sigma); (v) V. cholerae partially purified neuraminidase $\mathrm{G} 100 / \mathrm{N}_{2}(55 \mathrm{ImU} / \mathrm{ml})$; (vi) $V$. cholerae neuraminidase (Calbiochem); (vii) concentrated trypsin inhibitor

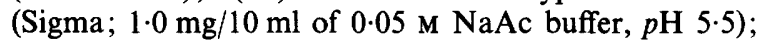
(viii) concentrated trypsin inhibitor $(2 \cdot 0 \mathrm{ml})+$ neuraminidase $\mathrm{G} 100 / \mathrm{N}_{2}(0.1 \mathrm{ml})+0.05 \mathrm{M} \mathrm{NaAc}$ buffer, $p \mathrm{H} 5.5$ $(0.05 \mathrm{ml})$; (ix) borate gelatin buffer, $p \mathrm{H} \mathrm{7.5;} \mathrm{(x)} \mathrm{cholera}$ enterotoxin (NIAID $; 3.0 \mathrm{~g} / 5.0 \mathrm{ml}$ of borate gelatin buffer,

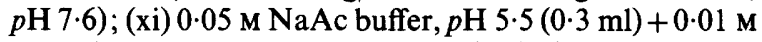
phosphate buffer, $p \mathrm{H} 7.5(0.05 \mathrm{ml})$; (xii) $0.05 \mathrm{M} \mathrm{NaAc}$ buffer, $p \mathrm{H} \mathrm{5.5}(0.05 \mathrm{ml})+0.01 \mathrm{M}$ phosphate buffer, $p \mathrm{H} 7.5$ $(0 \cdot 3 \mathrm{ml})$. Two frozen sections were left untreated to serve as additional controls.

Goblet-cell assay. The sections were examined by light microscopy and goblet cells were counted in 20 random fields. AB-positive cells were stained blue (periodateunreactive) or purple (periodate-reactive acid mucosubstances), whereas PAS-positive cells were stained magenta (neutral periodate-reactive mucosubstances). The data were analysed statistically by Student's $t$ test (twotailed); the goblet-cell counts in the untreated control or buffer-treated sections were compared with those in sections treated with neuraminidase preparations.

\section{Results}

The effect of $V$. cholerae neuraminidase on goblet-cell histochemistry

The untreated and neuraminidase-treated rat ileal-tissue sections were examined by light microscopy. In areas where the villi were in transverse section, distinct whorls of goblet cells were seen. In the control rat ileal section, the cells in these whorls were stained predominantly blue/purple and there were fewer magenta-stained cells (plate $a$ and $c$ ). However, when serial sections were treated with different amounts of $C$. perfringens or $V$. cholerae neuraminidase, there was a distinct change in the histochemical reaction and the goblet cells were stained predominantly magenta (plate $b$ and $d$ ). A similar effect was noticed with longitudinal sections of villi. Consequently, counts were made of the goblet cells that were stained either blue/purple or magenta by the alcian blue/PAS method. The number of cells stained by alcian blue was $553 / \mathrm{cm}^{2}$ field area in the untreated section. However, after treatment with neuraminidase for $24 \mathrm{~h}$ at $37^{\circ} \mathrm{C}$, there were only $282 / \mathrm{cm}^{2}$. Similarly, the numbers of magenta PAS-stained cells were $119 / \mathrm{cm}^{2}$ in the untreated and $193 / \mathrm{cm}^{2}$ in the neuraminidasetreated sections.

Statistical analyses revealed significant differences in the alcian blue counts $(p<0.0002)$ and PAS counts $(p<0.001)$ for the untreated and neuraminidase-treated preparations. There was no significant difference in the respective counts for 


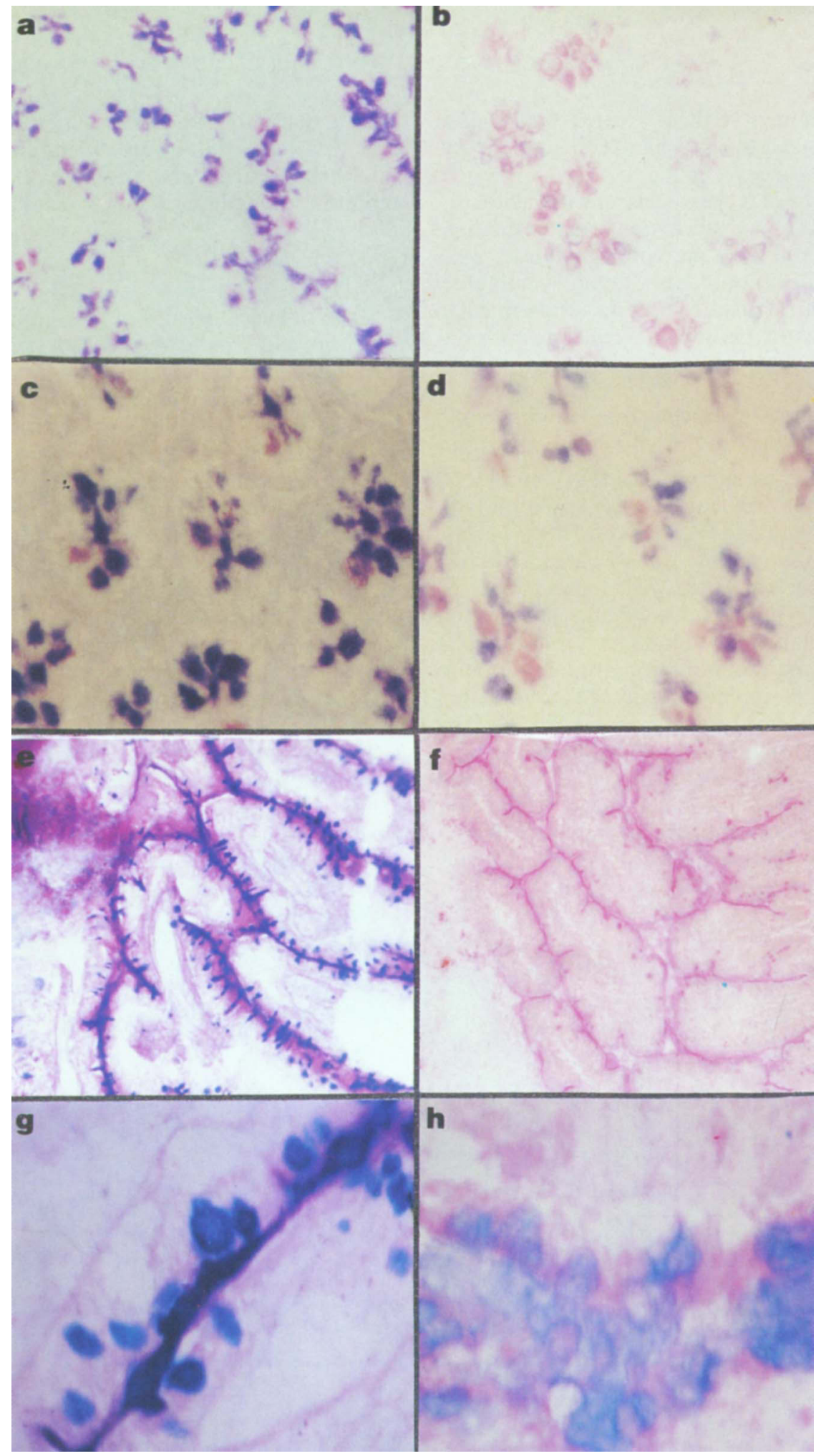

Plate. Rat ileum, longitudinal sections; $a, c$ are untreated controls; $b, d$ were treated with Worthington $C$. perfringens neuraminidase $136 \mathrm{ImU}$ for $24 \mathrm{~h}$ at $37^{\circ} \mathrm{C}$. Sections were stained with alcian blue/PAS at pH $2 \cdot 5$. Note the darker alcianophilic goblet cells $(a, c$, purple-stained) in the untreated sections and the lighter staining neutral mucosubstances in goblet cells treated with neuraminidase ( $b, d$, magenta-stained).

$(a, b \times 465, c, d \times 656)$ Rabbit ileum, transverse sections; $e, g$ are untreated controls; $f$ was treated with Koch-light $V$. cholerae neuraminidase 500 ImU, and $h$ was treated with $V$. cholerae $\mathrm{Gl} 100 / \mathrm{N}_{2}$ for $24 \mathrm{~h}$ at $37^{\circ} \mathrm{C}$. Some goblet cells in $h$ were evaginated after neuraminidase treatment. 
untreated sections and those treated with $0.05 \mathrm{M}$

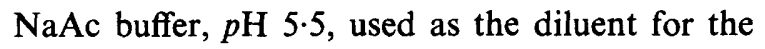
neuraminidase.

Histochemical reactions were similar with rat, guinea-pig or rabbit ileal sections treated with $V$. cholerae neuraminidase preparations (plate, $e-h$ ). Generally, rat ileum produced a better alcian blue/ PAS histochemical reaction and was economical to obtain, so further experiments were done with this material.

\section{The effect of different neuraminidase preparations on} the goblet-cell assay

The neuraminidase activities of four commercial enzyme preparations from $C$. perfringens or $V$. cholerae were compared with that of the $V$. cholerae $\mathrm{G} 100 / \mathrm{N}$ mucinase preparation. The most active commercial neuraminidase was derived from $C$. perfringens; $136 \mathrm{ImU}$ of the Sigma preparation reduced the alcian blue reaction for NANA (sialic acid, $\mathrm{N}$-acetylneuraminic acid) from $555 / \mathrm{cm}^{2}$ to $68 / \mathrm{cm}^{2}$ (figure). A similar quantity of the Worthington preparation was less active and reduced the count to $283 / \mathrm{cm}^{2}$ (figure).

With the $V$. cholerae preparations, the number of cells stained by alcian blue was $111 / \mathrm{cm}^{2}$ for $100 \mathrm{ImU}$ of the Calbiochem enzyme and $210 / \mathrm{cm}^{2}$ for $11 \mathrm{ImU}$ of the partially-purified $V$. cholerae $\mathrm{G} 100 / \mathrm{N}_{2}$ mucinase complex (figure).
Statistical analyses showed a significant difference between the alcian blue counts for the untreated sections and in those exposed to the neuraminidase preparations $(\mathrm{p}<0.0002)$.

\section{Discussion}

Stewart-Tull et al. (1986) showed that the thiobarbituric acid (TBA) assay was less sensitive than the methoxyphenol-neuraminate (MPN) assay as a monitor of specific neuraminidase activity in the $V$. cholerae mucinase complex. Montgomery (1970) discussed the isolation, fractionation and purity of glycoproteins and pointed out that it is difficult to prove that preparations are free from extraneous material. This is particularly true for the highlycharged mucins that produce viscous solutions. In such viscous solutions the neuraminidase may be prevented from reaching sites of specific action with a consequent lower level of NANA released. Furthermore, the number of carbohydrate groups per molecule of glycoprotein may influence the result of the in-vitro colourimetric assay.

Similarly, Aminoff (1961) noted that the reaction of neuraminic acid in the TBA assay was identical to that obtained with 2-oxo-3-deoxy sugar acids. Several other carbohydrate residues will give positive reactions in the TBA assay, including 2deoxyribose, 3-deoxy- and 3,6 dideoxyhexoses,

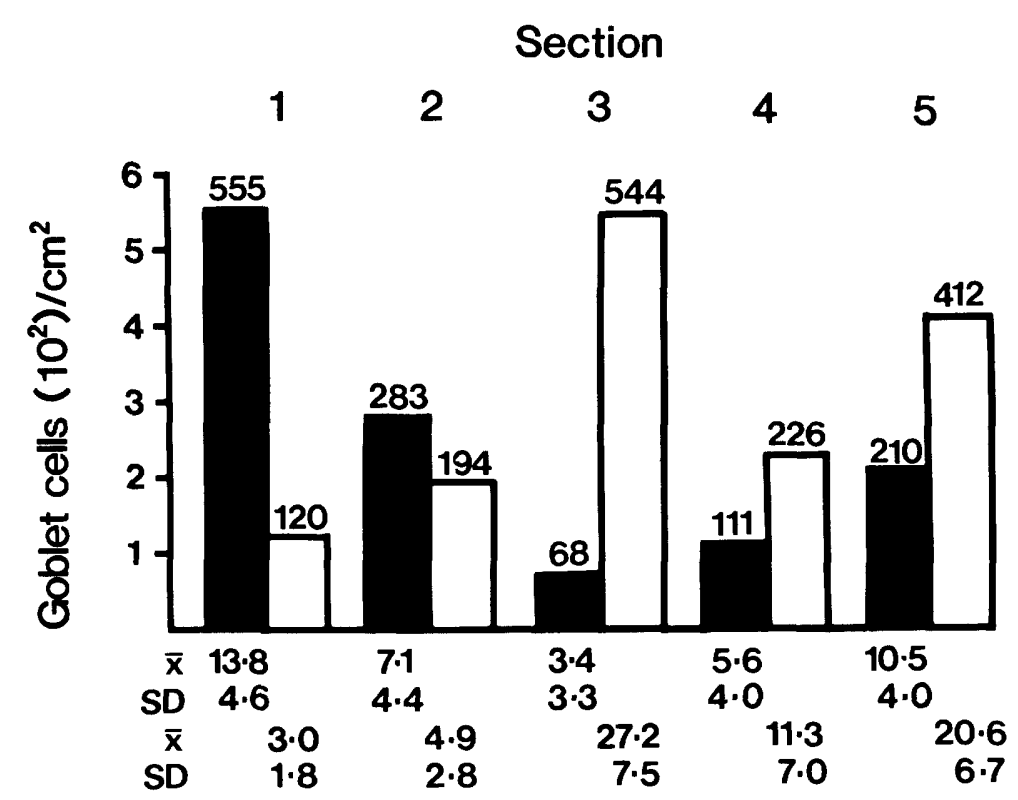

Figure. Counts of goblet cells in 20 random fields of rat ileum sections treated with various neuraminidase preparations. Section 1 , control untreated; 2, treated with Worthington $C$. perfringens enzyme $136 \mathrm{ImU} ; 3$, treated with Sigma $C$. perfringens enzyme $136 \mathrm{ImU} ; 4$, treated with Calbiochem $V$. cholerae enzyme $100 \mathrm{ImU}$; and 5, treated with $V$. cholerae $\mathrm{G} 100 / \mathrm{N}_{2}$ enzyme 11 ImU. The solid columns represent the number of normal alcianophilic goblet cells (purple-stained) and the open columns the number of goblet cells containing neutral mucosubstances after neuraminidase treatment (magenta-staining). 
together with the residues released by neuraminidase and endoglycosidase in the mucinase complex.

For these reasons, the use of the substrates $\mathrm{N}$ acetylneuraminlactose (Cassidy et al., 1965) or 2(3'methoxyphenyl-N-acetyl $\alpha$ neuraminic acid) (Palese et al., 1973) has been recommended for the in-vitro assay of neuraminidases. However, this type of assay provides sparse information about the role of the $V$. cholerae neuraminidase in the gut. The alcian blue/PAS histochemical staining procedure has been used to show that neuraminidase produced in situ will destroy the alcianophilia of the goblet cells. The present study has extended the work on the qualitative nature of the histochemical effect and it has been possible to quantitate the activity of the neuraminidase in the environment of a semi-natural experiment.

When unfixed frozen sections of rat ileum were used in studies to detect the presence of the neuraminidase in the $V$. cholerae mucinase complex, it was found that the aqueous solutions of the histochemical stains removed the neuraminidase substrate mucin. A similar problem was noted by Pearse and Tock (1965) and Tock and Pearse (1965) with liquid, chemical fixation procedures. The formaldehyde vapour method of Pearse and Tock (1965), as described by Culling (1974), considerably reduced the non-enzymic loss of intestinal mucin and preserved the goblet-cell mucin. This enabled the effect of $V$. cholerae neuraminidase to be assayed by the alcian blue/PAS reaction.

It was noticed also that the most distinct histochemical reaction occurred in sections of rat ileum after neuraminidase treatment. Forstner $\boldsymbol{e t}$ al. (1973) isolated and chemically examined the

\section{REFERENCES}

Aminoff D 1961 Methods for the quantitative estimation of $\mathbf{N}$ acetyl neuraminic acid and their application to hydrolysates of sialomucoids. Biochemical Journal 81 : 384-392.

Cassidy J T, Jourdian G W, Roseman S 1965 The sialic acids VI. Purification and properties of sialidase from Clostridium perfringens. Journal of Biological Chemistry 240:3501-3506.

Culling C F A 1974 Handbook of histopathological and histochemical techniques, 3rd edn. Butterworths, London. p. 54 .

Forstner J F, Jabbal I, Forstner G G 1973. Goblet cell mucin of rat small intestine. Chemical and physical characterization. Canadian Journal of Biochemistry 51 : 1154-1166.

Forstner J F, Roomi N W, Fahim R E, Forstner G G 1981 Cholera toxin stimulates secretion of immunoreactive intestinal mucin. American Journal of Physiology 240: C.1016.

Fraser A G, Smith J K 1975 Preparation of a glycoprotein fraction from pooled human plasma and its evaluation as a substrate for the assay of Clostridium welchii (C.perfringens) neuraminidase. Journal of Medical Microbiology 8: 235-249. goblet-cell mucin from rat intestines; after neuraminidase treatment (Sigma type VI, C. perfringens), $86.7 \%$ of the total sialic-acid residues were released from the rat goblet-cell mucin. Therefore, it seems likely that this native glycoprotein has readily accessible sialic-acid terminal carbohydrate residues that are susceptible to $V$. cholerae neuraminidase. In our study the neuraminidases of both $C$. perfringens and $V$. cholerae were active against rat goblet-cell mucin. Although Ramphal and Pyle (1983) found a similar effect with bovine submaxillary mucin, only the $V$. cholerae enzyme released NANA from mouse tracheal tissue. Whether these different findings can be attributed to differences in the steric configuration of the target sialic acid in the glycoprotein or to slight differences in enzyme specificity remains to be determined.

Forstner et al. (1981) found that cholera enterotoxin stimulated the secretion of sialomucin from the intestinal surface. In our study, treatment of rat ileal sections, fixed in paraformaldehyde vapour, with purified cholera enterotoxin, as expected, did not significantly alter the number of alcianophilic goblet cells. Nevertheless, the assay may be useful in monitoring the hypersecretion of sialomucin after intestinal stimulation with enterotoxin in vivo.

The goblet-cell histochemical assay provides a useful complement to the more artificial colourimetric assays, although the latter are more rapid and less substrate specific. The specificity of the alcian blue reaction for neuraminic acid proved that other studies with anti-neuraminidase antisera were confused totally by the presence of serum sialidase.

Hughes R C, Jeanloz R W 1964 The extracellular glycosidases of Diplococcus pneumoniae. I. Purification and properties of a neuraminidase and a $\beta$-galactosidase. Action on the $\alpha_{1}$ acid glycoprotein of human plasma. Biochemistry 3 : 15351543.

Montgomery R 1970 Glycoproteins. In: Pigman W, Horton D (eds) The Carbohydrates, vol 2B. Academic Press, London. pp 627-709.

Mowry R W, Winkler C H 1956 The coloration of acidic carbohydrates of bacteria and fungi in tissue sections with special reference to capsules of Cryptococcus neoformans, Pneumococci and Staphylococci. American Journal of Pathology 32 : 628-629.

Palese P, Bucher D, Kilbourne E D 1973 Applications of a synthetic neuraminidase substrate. Applied Microbiology 25: 195-201.

Pearse A G E, Tock E P C 1965 Preservation of tissue mucins by freeze-drying and vapour fixation. Journal of the Royal Microscopical Society 84:398.

Popenoe E A, Drew R M 1957 The action of an enzyme of Clostridium perfringens on orosomucoid. Journal of Biological Chemistry 228:673-683. 
Quintarelli G, Tsuiki S, Hashimoto Y, Pigman W 1961 Studies of sialic acid-containing mucins in bovine submaxillary and rat sublingual glands. Journal of Histochemistry and Cytochemistry 9:176-183.

Ramphal R, Pyle M 1983 Adherence of mucoid and non-mucoid Pseudomonas aeruginosa to acid-injured tracheal epithelium. Infection and Immunity 41 :345-351.

Spicer S S, Warren L 1960 The histochemistry of sialic acid containing mucoproteins. Journal of Histochemistry and Cytochemistry 8: 135-137.

Stewart-Tull D E S, Ollar R A, Scobie T S 1986 Studies on the Vibrio cholerae mucinase complex. I. Enzymic activities associated with the complex. Journal of Medical Microbiology 22:325-333.

Tock E P C, Pearse A G E 1965 Preservation of tissue mucins by freeze-drying and vapour fixation. I. Light microscopy. Journal of the Royal Microscopical Society 84:519-537.

Warren L 1959 The thiobarbituric acid assay of sialic acids. Journal of Biological Chemistry 234: 1971-1975.

Wheeldon E B, Pirie H M, Breeze R G 1976 A histochemical study of the tracheobronchial epithelial mucosubstances in normal dogs and dogs with chronic bronchitis. Folia Veterinaria Latina 6:45-58. 